\title{
Environmental Geological Studies on Bicess Island Area, Northwest Libya
}

\author{
Mohamed Abdelgalil $^{1 *}$, Ismail F. Shushan ${ }^{2}$ \\ ${ }^{1}$ Damietta University, Faculty of Science, Environmental Sciences Department, Egypt. \\ ${ }^{2}$ Al-Mergheb University, Faculty of Science at Alkhoms, Earth Sciences and Environment Dept., Libya.
}

Received: 24 May 2015 / Accepted: 12 October 2015

* Corresponding author:Abdelgalil@yahoo.com

\begin{abstract}
Due to the few number of islands encountered in the States of the continent of Africa bordering the Mediterranean Sea, Bicess Island may be considered as one of the most important geological features in Libya. The study represents an attempt to identify the threatening of wild birds on Bicess Island through the studying of the various geomorphologic and structural features as well as the stratigraphic sequence. Bicess Island is located west of the Alkhoms City at the mouth of Wadi Bicess which marks the junction of the Nafusa Mountain base with Mediterranean coast. The genesis of Bicess Island is mostly due to the breaking down caused by wave action with the help of the structural effects in the region. The length of the island reaches $240 \mathrm{~m}$, while the width is varying between $40 \mathrm{~m}$ and $160 \mathrm{~m}$. The depth of water at the southern part of Bicess Island reaches about 4 $\mathrm{m}$ and varies between $7 \mathrm{~m}$ and $12 \mathrm{~m}$ at the northwestern part and the northeastern part respectively. Bicess Island posses a rocky beach occupied by algae and characterized by highly steeped and irregular cliffs as well as coasts associated with bays and peaks. The presence of dense plant cover on Bicess Island as well as its separation of being surrounded by sea water caused the human activities to be very limited and the occupation of the island by a great number of wild birds build their nests within the holes existing in rocks belonging to Alkhoms Formation. Caves were found at the base of cliffs. The shape of the caves appears as long cylinders extend along zones of weakness with radius become less to the interior of the rocks. On the roof of the caves there were a lot of joints which became wider forming explosive holes. Land destructions by waves and landslides are the most important factors threatening wild bird lives. In order to protect wild bird populations as well as the unique morphological and geological features, the present study recommends Bicess Island to become a natural reserve.
\end{abstract}

Keywords: Libya; Bicess Island; Caves, Bird life; natural reserve 


\section{Introduction}

Globally, more than a billion people live near the coast and many of those reside only a few meters above sea level or behind an encroaching hazard, the edge of the coastal cliff (Small et al., 2000; Nicholls and Small, 2002). Various studies have documented the extent of coastlines that are undergoing erosion (USACE, 1971; Habel and Armstrong, 1978; Griggs and Savoy, 1985; Pope et al., 1999; Komar, 1997; Terich, 1987; Kelley et al., 1989; Carter et al., 1987; McCormick et al., 1984); Griggs, 1999). Because of the desirability of living directly on the coast, which in many regions means living on a cliff above an eroding coastline, there are significant short and long-term risks associated with the population migration to, and more intense development of, those areas. Coastal erosion has become an increasingly publicized regional and national issue that is going to affect the Nation for many decades.

In many coastline areas, irregular coasts may become more organized and aligned as a result of sea action which may deposit sand bodies in the form of barriers and tongues either at points where coastlines changing their direction suddenly or in the front of river estuarine gulfs or through bays entrance or sometimes between land margins and adjacent islands. As waves enter shallow waters nearby the beach, they become broken where their lower parts become forced by friction at the bottom. The wave crest with its powerful energy may advance forward and become broken. Waves may differ in their crest volume; some may resemble the sand rippling, while others appear in the form of strong storm waves supported with the high wind speed capable to destroy the beach components at the lowered coastlines (Elatrash et al., 2006). When waves attack beaches, they become eroded strongly or weakly depending on the original morphology of the beach. The degree and speed of erosion of the beach may depend on many factors, such as the degree of resistance of the rocks that form the beach and the intensity of wave action attacking the beach.

\section{Location of study area}

Bicess Island is situated west of Alkhoms city at the mouth of Bicess valley (Fig-1). The current study represents an attempt to identify the threatening of wild birds on Bicess Island through the studying of the various geomorphologic and structural features as well as the stratigraphic sequence of the area.

\section{Method of study}

Field investigations including determining the different geomorphologic and structural characteristics of the Island and collecting representative samples of the stratigraphic sequence documented with petrographic investigations using a polarized microscope with photo-camera.

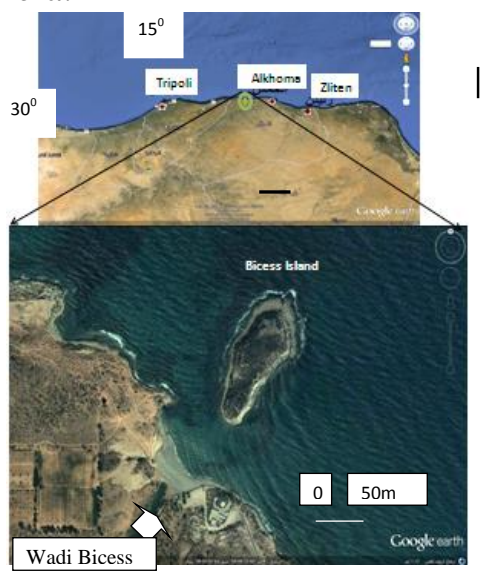

Fig 1: Satellite image showing location of study area and the conjunction of Wadi Bicess with Mediterranean Sea at Bicess Island.

\section{Geomorphology}

The area of study represents the junction of the Nafusa Mountains with Mediterranean coast. The interface of Nafusa Mountain is situated to the west of Alkhoms city and may consider as a surface of erosion intersected by a number of valleys with many tributaries. The most tributaries in the region exhibiting parallel drainage patterns and cutting sedimentary rocks in the direction of Mediterranean Sea. The most essential geomorplogical features include Wadi Bicess and Bicess Island.

Wadi Bicess surrounded by rocky cliffs with highest point reaches to $220 \mathrm{~m}$ from sea level. Bicess Island is located near the shore line, reaches about $30 \mathrm{~m}$ high and descends steeply sides (Fig2). The width of the island varies between $160 \mathrm{~m}$ at its northern part and $40 \mathrm{~m}$ at its southern one, while the length of the island reaches to about 240 $\mathrm{m}$. The water depth is about $4 \mathrm{~m}$ in the south, and varies between $7 \mathrm{~m}$ and $12 \mathrm{~m}$ at the northwestern and northeastern parts respectively. Generally, the beach of the island is rocky and permitted the 
accumulation of water and some sort of algae and gastropods on its surface (Fig. 3).

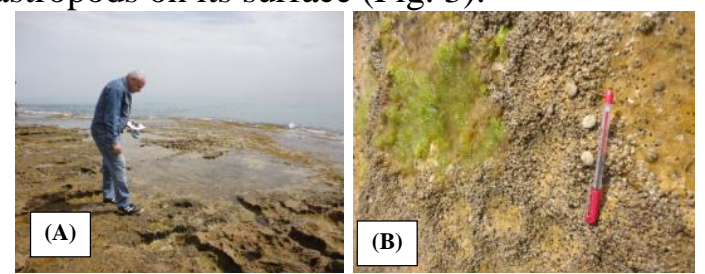

Fig 3: (A) Accumulations of shallow water. (B) Accumulations of algae and gastropods on Bicess Island beach.

The most important observed erosion features are sea cliffs, caves, blow holes, and wave-cut platform. Sea cliffs are the most important erosion features formed by the wave action along the shore of Bicess Island. Erosion processes can carve a cliff face slowly into hard rocks and rapidly into soft rocks (Sunamura, 1983). The amount of wave-induced erosion is a function of the energy expended against the cliff by the waves, through the compressional force of impact and the tractive force of uprush (Trenhaile, 1987; Sunamura, 1992). However, some initiate as scarps of large landslides or faults (Moore et al., 1989; Kershaw and Guo, 2001).

Caves are formed at the base of cliffs which have been subjected to sea wave action. Caves appear in the form of cylinder-like tunnels along zones of weakness and decrease in diameter as we head towards the inside. Many joints have been identified in the roof caves which become wider and swell up forming blow holes. The holes occur as a result of the continued compression action which causing water to flare-up through the cave and flow-out into air. The emergence of water through the caves occurs due to compression strength of waves when rush violently inside the cave at the bottom of the collar hole (Figs 4 and $5)$.
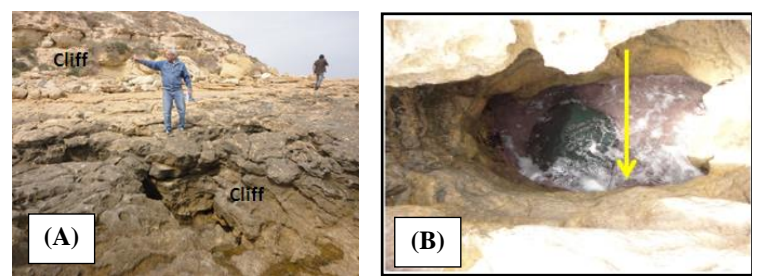

Fig. 4: (A) Formation of cliffs on the rocky beach of Bicess Island. (B) Close-up view showing the creation of a blow hole. Note the presence of water in its collar.

Erosion effects of wave action and the retreat of cliffs lead to the development of wave-cut platform (Fig. 5). The rocky material that resulted from the erosion may swing in motion by the waves in the tidal zone. The swing motion of this rocky material along the wave-cut platform that gently-slopes towards the sea, may enhances the erosion process and result in more polished surface of the platform.

The erosion phase in the area of study could be considered as the youth stage where Bicess Island is characterized by irregular, highly-steep cliffs and has coasts occupied by capes and bays.

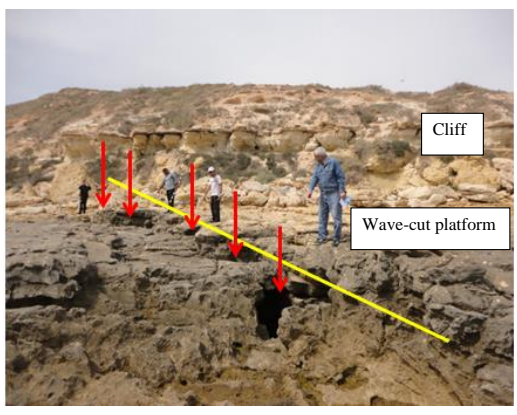

Fig. 5: The emergence of water through the caves occurs due to compression strength of waves when rush violently inside the cave at the bottom of the collar hole. Note the zone of weakness (yellow solid line) in the rocks along which the holes were formed.

Bicess beaches exhibit a variety of geomorphologic features resulted from deposition, the most important is the pelagic zone or the Beach which denotes areas from the shore marked either by accumulations of gravel and sand in zones laying between low-tide and hightide limits, or may be just a bunch of unstable boulders and gravel rolled by waves at the bottom of cliffs. It is noted that, the pelagic zone on the elevated coasts of Bicess Island considered narrow due to deep water levels close to land margin, while lowered coasts exhibit broad pelagic zones within high-tide and low-tide limits. Also, pelagic zones form inside bays limited by two land apexes. The margins of land apexes subjected to wave action and become gradually eroded causes deposition on the interior margins of the bay close to the main cliff (Fig. 6).

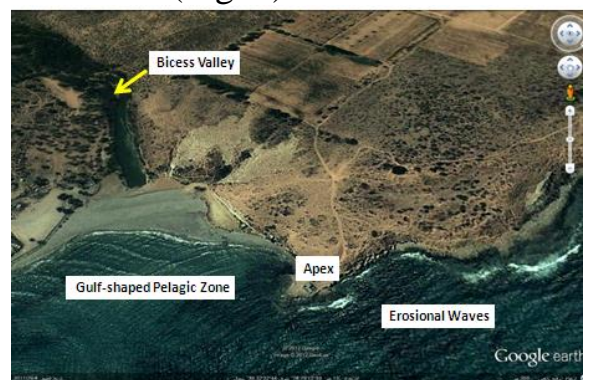

Fig. 6: The pelagic zone of Bicess Island (Gulf-shaped pelagic zone). Note the steep coastal cliff with rocky headlands. 


\section{Stratigraphic Sequence}

Beds outcropping in Bicess area show rock units of Alkhoms Formation (Middle Miocene) which mainly include, from base to top, sandstones, sandy-limestone followed by limestone. The seacliff exposures eroded into marine terraces. The stratigraphic sequence is shown in Table (1) and Figs (7 and 8).

The petrographic studies of Alkoms Formation (Alnaqaza Member) revealed that, it consists of medium-grained sandstones mainly composed of sub-rounded quartz particles (Fig. 9A). This sandstone horizon is overlain by fossiliferous sandy-limestone beds deposited in a shallow water environment (Figs 9B and 10A). This is followed by a sandy-limestone beds deposited in a relatively deep environment (Fig. 10B). The presence of quartz grains engulfed inside the micrite component may indicate the role of winds as a transporting agent in the environment of deposition. Stratified limestone (chalky) covering a sandy-limestone denoting transgression of the sea during Miocene.

Table (1): The stratigraphic sequence at Alkhoms area (modified after Mann, 1975)

\begin{tabular}{|c|c|c|c|c|}
\hline Description & \begin{tabular}{|c|} 
Thickness \\
meters
\end{tabular} & Member & Formation & Age \\
\hline Gravels and boulders & - & & $\begin{array}{c}\text { Recent } \\
\text { Valley } \\
\text { Deposits }\end{array}$ & \multirow{7}{*}{ 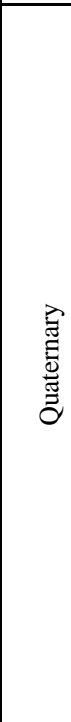 } \\
\hline $\begin{array}{c}\text { Coastal- calcareous } \\
\text { sandstones }\end{array}$ & $10-20$ & & $\begin{array}{c}\text { Eolian } \\
\text { Deposits }\end{array}$ & \\
\hline \begin{tabular}{|c|} 
Eolian materials \\
intercalated with \\
gravels and silica grains \\
as will as rare calcarous \\
shells.
\end{tabular} & & & $\begin{array}{l}\text { Eolian- } \\
\text { Marine } \\
\text { Deposits }\end{array}$ & \\
\hline $\begin{array}{l}\text { Clay, sandy limestone } \\
\text { associated with salts } \\
\text { and gypsum crystals } \\
\end{array}$ & $1-3$ & & $\begin{array}{l}\text { Sabkha } \\
\text { Deposits }\end{array}$ & \\
\hline \begin{tabular}{|c|} 
Calcarenite with \\
sporadic siltstone lenses
\end{tabular} & $30-40$ & & Qarqaresh & \\
\hline $\begin{array}{l}\text { Siltstone, conglomeratic } \\
\text { sandstone with } \\
\text { calcareous and } \\
\text { gypsiferous shells }\end{array}$ & 15 & & Jefara & \\
\hline \begin{tabular}{|c|} 
Consolidated \& looes \\
gravel, inter- calations \\
of calcareous shells. \\
\end{tabular} & 25 & & \begin{tabular}{|} 
Qasar Al- \\
Haj
\end{tabular} & \\
\hline $\begin{array}{c}\text { Clay, sandy-calcarenite, } \\
\text { conglomer- ate, marly- } \\
\text { limestone, limestone }\end{array}$ & 100 & & Alkhoms & 这 苋 \\
\hline $\begin{array}{c}\text { Dolomitic limestone to } \\
\text { dolomite with chert } \\
\text { nodules }\end{array}$ & 200 & & Nalut & \multirow{3}{*}{ 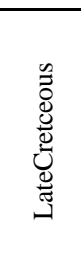 } \\
\hline $\begin{array}{c}\text { Marl. Claystone + } \\
\text { gypsum crystals }\end{array}$ & 380 & $\begin{array}{l}\text { Yefern } \\
\text { Marl } \\
\end{array}$ & \multirow[b]{2}{*}{ Sidi Assed } & \\
\hline $\begin{array}{c}\text { Dolomitic limestone to } \\
\text { dolomite }+ \text { quartz annd } \\
\text { quartzite interbbeds }\end{array}$ & $30-45$ & Ain Tobi & & \\
\hline
\end{tabular}

Fig. 7: The stratigraphic sequence of Bicess Island (sea transgression).

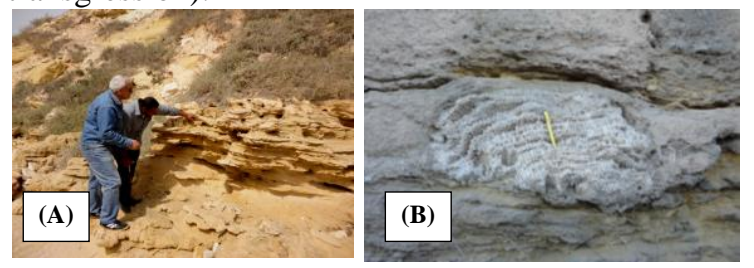

Fig. 8: Alkhoms Formation; (A) Cross-bedded sandstone. (B) Coral reef in fossiliferous sandylimestones.
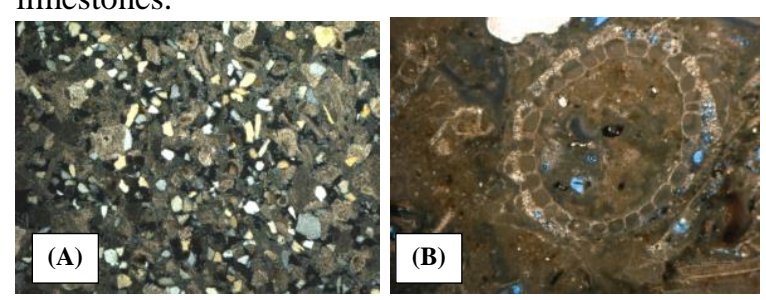

Fig. 9: A microscopic photos (x2.5) of Alkhoms Formation; (A) shows sub-rounded medium-grained sandstone. (B) Denoting the fossiliferous sandylimestone.
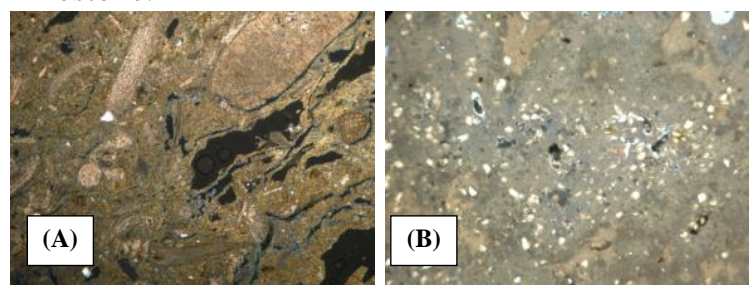

Fig. 10: A microscopic photos $(x 2.5)$ of Alkhoms Formation; (A) denoting the Bivalves and Bryozoas in fossiliferous sandy-limestones of Alkhoms Formation. (B) Quartz grains within the micrite component of the sandy-limestone.

\section{Sea waves control on the deformation of the coast}

As a result of erosional and depositional processes, the shore line of Bicess Island extends nearly N67W - S67E perpendicular to the resultant wave energy (Abdelgalil, 2009). When waves reach the base of a cliff, they can erode the cliff material directly or they can erode loose material that has collected at the cliff base which 
destabilize the cliff and ultimately induce failure of the overlying material (Edil and Vallejo, 1980). It is the combination of subaerial and marine processes, as well as the nature of the constituent materials, that create distinctive coastal cliffs (Pethick, 1984).

The creation of Bicess Island played a principal role in the power concentration as a result of the breakdown of waves on its body (Fig. 11). The shore platform seaward of the coastal cliff in Bicess Island is widest where the cliff receives the most intense daily action of waves. Consequently, the northern shoreline of the island becomes more eroded than the other sides. The western and eastern shoreline sides were more eroded than the southern one. The width of the sea platforms in Bicess Island is about 40 meters to the north, 20 meters to the west, 10 meters to the east and become less to about nothing to the south (Fig. 12). Moreover, Bryan and Stephens (1993) noted that, the shore platform seaward of the coastal cliff in Hanauma Bay, Hawaii, is widest where the cliff receives the most intense daily heating and therefore the most intense salt weathering.

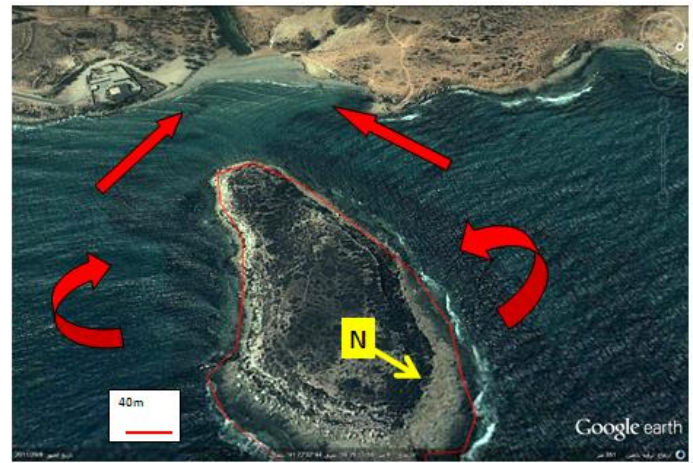

Fig. 11: The breakdown of sea waves on the rocky peaks of the island. Note the more extended sea platform to the north compared to the less extended ones in west, east and south.
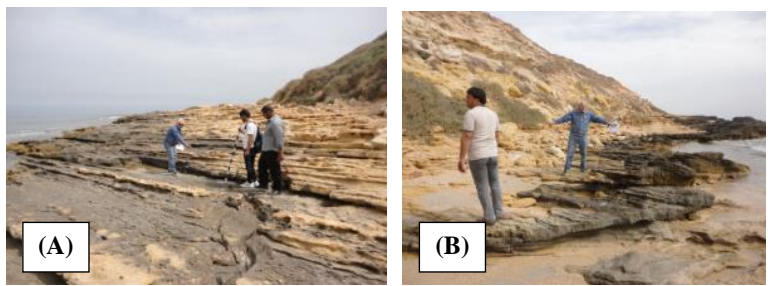

Fig. 12: (A) Extended sea platform in the west; (B) Less extended sea platform in the east.

\section{The catastrophic action of waves and structural effects}

Coastal morphology often correlates closely with tectonic setting (Inman and Nordstrom, 1971). The genesis of Bicess Island is mostly thought to be related to the catastrophic action of sea waves coupled with the structural controls in the region, where it is noted that, the island has influenced by a number of faults that extend NE- SW in the same direction of the resultant wave energy (Fig. 13). Field observations show that, the rocky capes extend NW-SE, where erosion by broken wave action is found to affect the area essentially in the NE-SW, parallel to the vertical joint assemblages developed in the area, which could result in the formation of cliffs. Joints and faults can serve as locations of high susceptibility to slope failure in otherwise stable rock (Benumof and Griggs, 1999; Griggs and Trenhaile, 1994). Wave energy may erode the lowermost rocks that gradually broken and cause the destruction of the uppermost rocks in the form of erratic blocks down cliffs. Waves attack the weaker zones of the fractures and joints and form inlet while the more resistant rock is left behind as points (Fig. 13B).
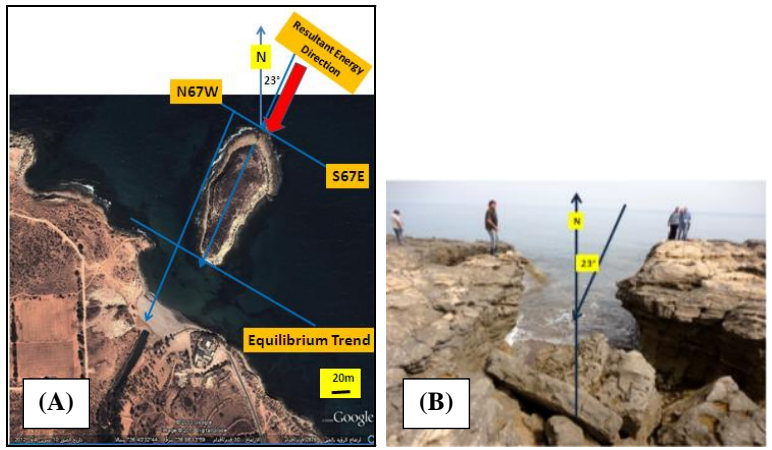

Fig 13: (A) The orientation of Bicess shoreline parallel to equilibrium trend; (B) The structural control on Bicess island genesis. Note the NE-SW faults run parallel to the resultant wave energy.

\section{Threatening the lives of wild birds}

The presence of dense vegetation on Alkhoms Formation rocks in the Bicess island (Fig. 14A) as well as its separation by water on all sides may helped in the inexistence of human activity on the island (or less frequent to some extent), hence, the reproduction of wild birds took place which used to build their nests within Alkhoms formation rocks.

Field observations showed the large number of wild birds on the island (Fig. 14B), and as due to the proximity of the island from the shore line, some holidaymakers who frequented during the summer find it easier to catch the young birds that existed in their nests built in rock gaps of Alkhoms Formation. The main problems facing the area of study may include land destructions by waves and 
landslides which acting negatively on lives of wild bird populations on the island.
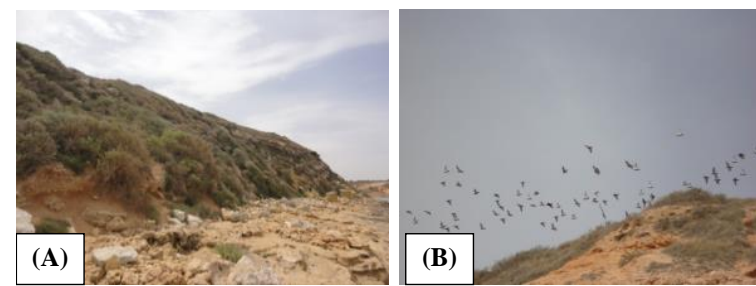

Fig 14: (A) The presence of vegetation on Alkhoms Formation rocks protected bird nests on the Bicess Island; (B) Large number of birds live among Alkhoms Formation rocks in Bicess Island.

\section{Conclusions}

The geomorphologic features in Bicess region is mainly represented by the Bicess valley and Bicess island which located close to beach line. The beach of the island is rocky which permitted some sort of algae to grow on its surface.

Erosion landforms on the island are represented mainly by sea cliffs, caves, blow holes and sea platforms. Bicess Island characterized by irregular, highly steep cliffs and having shorelines consisting of peaks and bays, therefore the erosion phase on the island could be considered in the youth stage.

The bed units outcropping belong to Alkhoms Formation (Middle- Miocene) which mainly represented from base to top by sandstones and sandy-limestone followed by limestone. Microscopic (petrographic) studies of Alkhoms Formation rocks (Alngaza Member) convinced that they consisted of medium sandstone characterized by subrounded quartz grains deposited in a relatively shallow environment; followed by fossiliferous sandy-limestone deposited in shallow environment as well as sandy-limestone deposited in relatively deeper environment; indicating the sea transgression phase during the Miocene.

The shore of the island facing the catastrophic action of the waves becomes more eroded than the other parts. Therefore, the northern coast of the island is more eroded followed by the less eroded parts in the west, east and then south. Hence, the broadness of the sea platform in the northern island reaches about $40 \mathrm{~m}$, while $20 \mathrm{~m}$ to the west, $10 \mathrm{~m}$ to the east and almost non-existent to the south.

Bicess Island has affected by NE $-\mathrm{SW}$ fracture system parallel to the resultant wave energy direction which helped the catastrophic wave action on the island. Therefore, Bicess Island genesis is mostly thought to be related to the catastrophic action of waves coupled with the structural controls in the region.

The presence of vegetation on Bicess Island as well as its separation of being surrounded by sea water caused the human activities to be very limited and the occupation of the island by a great number of wild birds. Land destructions by waves and landslides are the main factors threatening wild bird lives.

\section{Recommendations}

The present study recommends the Bicess Island to be a natural reserve as to protect the island and its components that represented by the unique geological and geomorphologic features and as well wild bird populations.

\section{References}

Abdelgalil, M. (2009): Geo-Environmental study on Marsa Zliten area, northwest Libya. Journal of Environmental Sciences, Vol. 34.

Benumof, B.T. and Griggs, G.B. (1999): The dependence of seacliff erosion rates on cliff material properties and physical processes; San Diego County, California: Shore and Beach, v. 67, no. 4, p. 29-41.

Bryan, W.B., and Stephens, R.S. (1993): Coastal bench formation at Hanauma Bay, Oahu, Hawaii: Geological Society of America Bulletin, v. 105, p. 377-386.

Edil, T.B., and Vallejo, L.E. (1980): Mechanics of coastal landslides and the infl uence of slope parameters, in Koh, S. L., ed., Mechanics of landslides and slope stability: Engineering Geology, v. 16, p. 83-96.

Elatrash, M., Abdelgalil, M. and Okasha, A. (2006): A study on the ancient Libda Sea Port and its beach characteristics. Libda City, Libya. Journal of Environmental Sciences, Vol. 32.

Carter, C.H., Neal, W.J., Haras, W.S., and Pilkey, O.H. (1987): Living with the Lake Erie shore: Durham, North Carolina, Duke University Press, 255 p.

Griggs, G.B. (1999): The protection of California's coast; past, present and future: Shore and Beach, v. 67 , no. 1, p. $18-28$.

Griggs, G.B., and Savoy, L. (1985): Living with the California coast: Durham, North Carolina, Duke University Press, 393 p.

Griggs, G.B., and Trenhaile, A.S. (1994): Coastal cliffs and platforms, in Carter, R.W.G., and Woodroffe, 
C.D., eds., Coastal evolution; Late Quaternary shoreline morphodynamics: Cambridge, Cambridge University Press, p. 425-450.

Habel, J.S., and Armstrong, G.A. (1978): Assessment and atlas of shoreline erosion along the California coast: State of California, Dept. of Navigation and Ocean Development, 277p.

Inman, D.L, and Nordstrom, C.E. (1971): The tectonic and morphologic classifi cation of coasts: Journal of Geology, v 79: p. 1-21.

Kelley, J. T., Kelley, A.R., and Pilkey, O.H., Sr. (1989): Living with the Maine coast: Durham, North Carolina, Duke University Press, 174 p.

Kershaw, S., and Guo, L. (2001): Marine notches in coastal cliffs; indicators of relative sea-level change, Perachora Peninsula, central Greece: Marine Geology, v. 179, p. 213-228.

Komar, P.D., 1997, Erosion of a massive artifi cial "landslide" on the California coast: Shore and Beach, v. 65, no. 4, p. 8-14.

Mann, K. (1975): Geological map of Libya: Sheet: Alkhums N 1 33-14 Explanatory booklet-Ind. Res. Cent. Tripoli, 88P.

McCormick, L.R., Pilkey, O.H., Jr., Neal, W.J., and Pilkey, O.H., Sr. (1984): Living with Long Island's south shore: Durham, North Carolina, Duke University Press, $157 \mathrm{p}$.

Moore, J.G., Clague, D.A., Holcomb, R.T., Lipman, P.W., Normark, W.R., and Torresan, M.E. (1989): Prodigious submarine landslides on the Hawaiian Ridge: Journal of Geophysical Research, v. 94, no. B12, p. 17,465-484.
Nicholls, R.J., and Small, C. (2002): Improved estimates of coastal population and exposure to hazards released: Eos, Transactions, American Geophysical Union, v. 83, no. 28, p. 301,305.

Pethick, J. 1984, An introduction to coastal geomorphology: New York, Edward Arnold, 260p.

Pope, J., Stewart, C.J., Dolan, R., Peatross, J., and Thompson, C.L. (1999): The Great Lakes shoreline type, erosion, and accretion: Vicksburg, Mississippi, U.S. Army Corps of Engineers, 1 sheet with text, 1:2,000,000.

Small, C., Gornitz, V., and Cohen, J.E. (2000): Coastal hazards and the distribution of human population: Environmental Geoscience, v. 7, p. 3-12.

Sunamura, T. (1983): Processes of seacliff and platform erosion, in Komar, P.D., ed., CRC handbook of coastal processes and erosion: Boca Raton, Florida, CRC Press, p. 233-265.

Sunamura, T. (1992): Geomorphology of Rocky Coasts: New York, John Wiley and Sons, 302 p.

Terich, T. A. (1987): Living with the shore of Puget Sound and the Georgia Strait: Durham, North Carolina, Duke University Press, 165 p.

Trenhaile, A.S. (1987): The geomorphology of rock coasts: Oxford, Oxford University Press, 384 p.

USACE (United States Army Corps of Engineers) (1971): National Shoreline Study-California Regional Inventory: San Francisco, California, Corps of Engineers, District Office, 105 p.

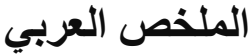

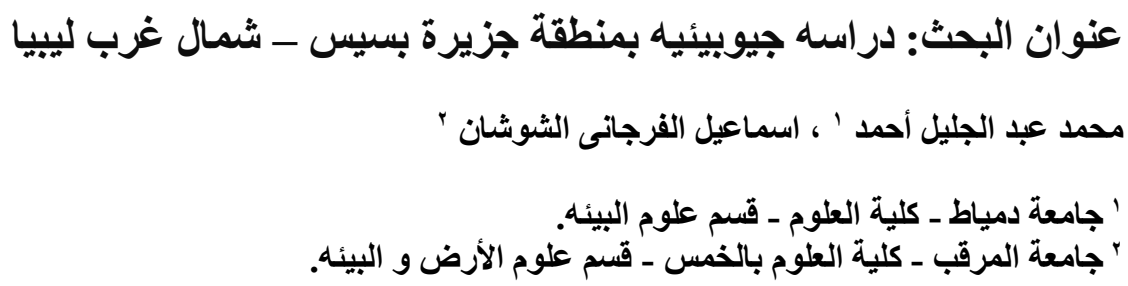

تمثل جزيرة بسيس أحد المعالم الجيولوجيه الهامه بليبيا وربما يرجع ذلك لقلة عدد الجزر المتواجده بدول

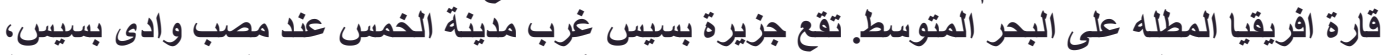

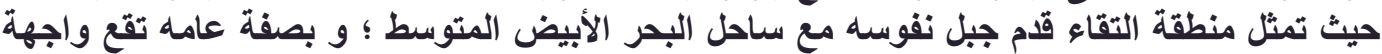

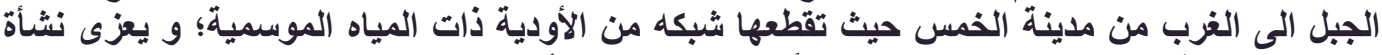

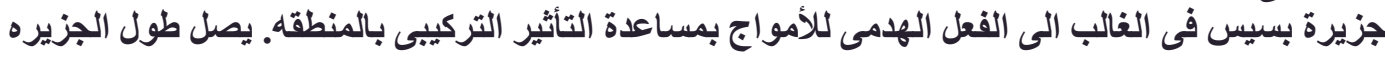

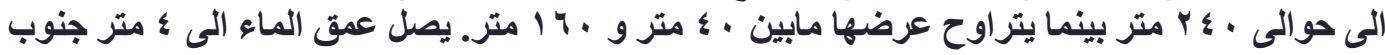

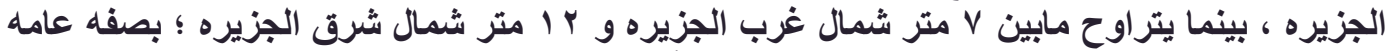

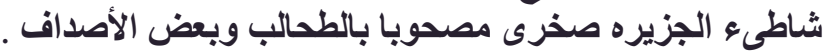

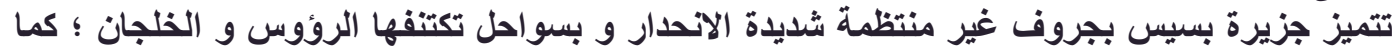

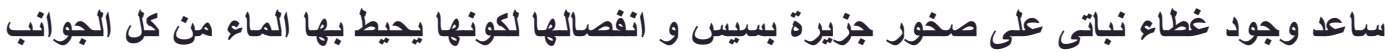




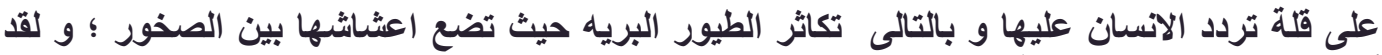

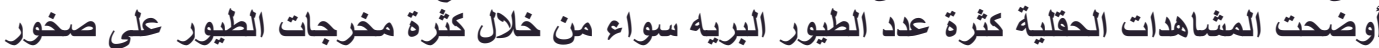

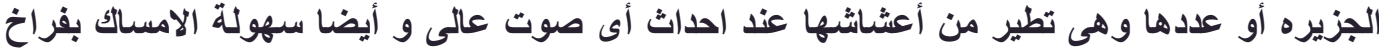

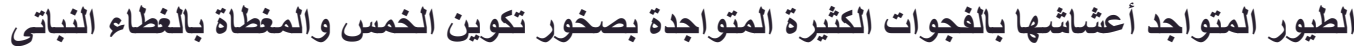

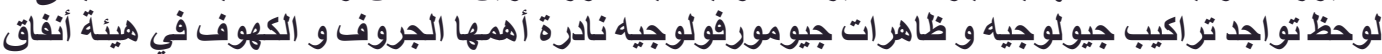

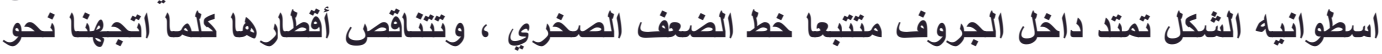

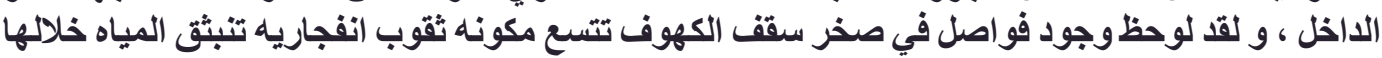

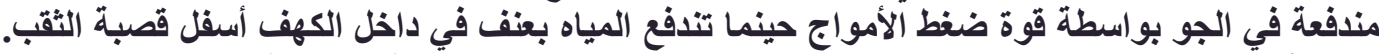

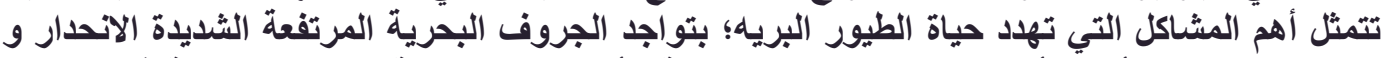

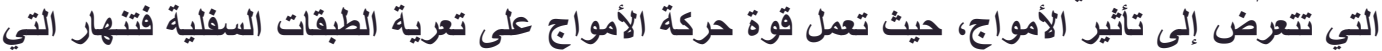

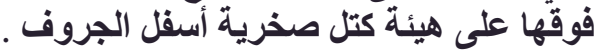

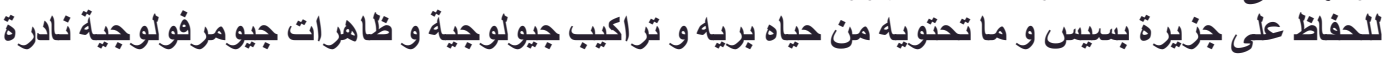
يوصى أن تكون جزيرة بسيس محميه طبيعية. 